\title{
Pengaruh Sistem Pemeliharaan secara Intensif dan Semi Intensif pada Itik Magelang
}

\author{
Effect of Intensive and Semi-intensive Maintenance System on Magelang Ducks
}

\author{
A. Rahayu' ${ }^{1}$, S. Ratnawati ${ }^{2}$, R. W. Idayanti ${ }^{1}$, B. Santoso ${ }^{1}$, dan N. A. Luthfiana ${ }^{1}$ \\ ${ }^{1}$ Program Studi Peternakan, Fakultas Pertanian, Universitas Tidar \\ ${ }^{2}$ Program Studi Manajemen, Fakultas Ekonomi, Universitas Tidar \\ Jalan Kapten Suparman No. 39 Magelang \\ Correspondinge-mail: ayu.rahayu@untidar.ac.id
}

\begin{abstract}
The duck was a local water poultry that originated from Magelang area. The aim of this study was to evaluate the weight and the weight of the duck eggs that are maintained intensive and semi-intensive. Hypotheses of the study that there was a difference between the body weight and the eggs weight in Magelang ducks that were maintained in intensive and semi-intensive systems. The research samples were 100 of Magelang ducks over 6 months old, consisting of male ducks 4 heads and ducks 96 heads. The observed parameters were body weight and egg weight. Samples were tested using T-test paired samples. The test results showed that the T value counts the body weight by 6.637 and the egg weight 3.242 . This stateed that there was a significant difference in body weight and the weight of the eggs between the intensively maintained and semi-intensive ducks. The conclusion of the maintenance of a semi-intensive maintenance system had a great potential to increase body weight faster as $0.265 \mathrm{~kg} / \mathrm{head}$ and the quantity also quality of the egg was better.
\end{abstract}

Key words: intensive, Magelang duck, semi-intensive

\begin{abstract}
ABSTRAK
Itik Magelang merupakan ternak unggas air lokal yang berasal dari daerah Magelang. Tujuan dari penelitian ini adalah untuk mengevaluasi bobot badan dan bobot telur itik yang dipelihara secara intensif dan semi intensif. Hipotesis dari penelitian ini bahwa ada perbedaan antara bobot badan dan bobot telur Itik Magelang yang dipelihara secara intensif dan semi intensif. Sampel penelitian ini adalah 100 ekor Itik Magelang yang berumur lebih dari 6 bulan, yang terdiri dari itik jantan 4 ekor dan itik betina 96 ekor. Parameter yang diamati adalah bobot badan dan bobot telur. Sampel diuji menggunakan paired sample T-test. Hasil uji menunjukkan bahwa Nilai t hitung bobot badan sebesar 6,637 dan bobot telur 3,242. Hal ini menyatakan bahwa ada perbedaan yang signifikan terhadap bobot badan dan bobot telur antara itik yang dipelihara secara intensif dan semi intensif. Kesimpulan dari pemeliharaan sistem pemeliharaan semi intensif memiliki potensi yang besar untuk meningkatkan bobot badan lebih cepat yaitu $0,265 \mathrm{~kg} /$ ekor dan kuantitas serta kualitas telur yang lebih baik.
\end{abstract}

Kata kunci: intensif, itik Magelang, semi intensif

\section{PENDAHULUAN}

Magelang merupakan salah satu kabupaten di provinsi Jawa Tengah yang berdasarkan SK Menteri Pertanian No.701/Kpts/PD.410/2/2013 (Kementerian Pertanian, 2013) menetapkan bahwa Itik Magelang merupakan rumpun itik asli Indonesia. Populasi Itik Magelang di Kabupaten Magelang cukup tinggi terbukti ada sekitar 7 Kecamatan dengan populasi diatas 9.000 ekor yaitu Muntilan, Mertoyudan, Ngluwar, Sawangan, Bandongan, Mungkid, Dukun dan Secang (Dinas Peternakan dan Perikanan Kab. Magelang, 2015). Itik adalah salah satu jenis unggas air yang banyak dipelihara oleh peternak untuk diambil daging dan telurnya. Itik Magelang memiliki ciri- ciri yaitu seluruh tubuhnya hampir berawarna cokelat terutama pada itik betina, sedangkan pada itik jantan terdapat tambahan warna hitam pada bagian kepalanya. Pada jenis Itik Magelang terdapat warna putih pada bagian leher yang menyerupai kalung. Banyak peternak yang menyebut Itik Magelang dengan sebutan itik kalung (Kementan, 2013). Produksi telur Itik Magelang dapat mencapai 200 butir per tahun dengan manajemen pemeliharaan yang baik. Menurut Ismoyowati dan Purwantini (2013) itik jantan memiliki BB 1,8-2,5 $\mathrm{kg}$ dan itik betina memiliki BB 1,5-2,0 kg. Dari penelitian yang dilakukan oleh Wulandari et al. (2015) bahwa ukuran sayap itik magelang berkisar antara 34-36 $\mathrm{cm}$. 
Dusun Sempu yang berada di Kecamatan Secang, Kabupaten Magelang adalah salah satu daerah yang masyarakatnya banyak memelihara jenis Itik Magelang baik dengan cara intensif maupun semi intensif. Itik Magelang menjadi ternak pilihan untuk mengembangkan peternakan yang ada di Dusun Sempu. Selain itu, untuk meningkatkan perekonomian dan sumber daya manusia yang ada di dusun tersebut. Dengan bantuan dari pemerintah desa setempat. Pengembangan Itik Magelang dilakukan dari tahap ke tahap meliputi sosialisasi terhadap kelompok peternak, penyaluran bantuan berupa Itik Magelang, dan pengontrolan dalam pemeliharaannya. Sehingga manajemen pemeliharaan yang dilakukan oleh peternak di Dusun Sempu sesuai dengan arahan dan menghasilkan produksi daging dan telur sesuai standar pasar. Harga setiap ekor itik yaitu berkisar antara $\mathrm{Rp} \quad 60.000,00$ hingga $\mathrm{Rp}$ $80.000,00$ sedangkan harga jual telur itik yaitu Rp 2.500,00. Namun dengan adanya pandemi covid 19, harga jual telur itik menurun sampai $\mathrm{Rp}$ 2.000,00. Dikarenakan penjualan yang sulit dipasaran yang akan menyebakan penumpukan hasil telur di kelompok ternak.

Kebutuhan daging unggas terutama itik semakin meningkat. Dikarenakan harga daging unggas lebih terjangkau dibandingkan harga daging ternak ruminansia seperti sapi. Hal tersebut yang menjadikan peternak banyak mengembangkan Itik Magelang. selain untuk mencukupi kebutuhan daging dan telur itik. Juga untuk menyeimbangkan dengan penjualan daging unggas lainnya seperti ayam broiler. Dari segi pemeliharaan Itik Magelang, dapat dilakukan dengan beberapa cara diantaranya intensif dan semi intensif. Pemeliharaan intensif yaitu pemeliharaan yang dilakukan dengan cara dikandangkan dengan tujuan untuk memudahkan dalam pengontrolan dan pemberian pakan. Selain itu, juga utuk meminimalisir dari predator lain seperti ular ataupun garangan. Dalam tahap produksi atau fase layer, banyak dijumpai peternak yang memelihara itik dengan cara menggunakan alas litter atau kandang battery. Pemeliharaan semi intensif yaitu pemeliharaan yang dilakukan dengan cara dikandangkan dan diumbar atau nama lainnya diangon.

Tujuan dari pemeliharaan semi intensif yaitu untuk meminimalisir biaya pakan yang melonjak tinggi dan memperoleh pakan tambahan dari sawah atau rawa-rawa seperti cacing, keong, serangga kecil dan biji-bijian yang banyak mengandung nurient yang baik untuk meningkatkan produksi daging dan telurnya. Oleh karena itu, tujuan penelitian ini untuk mengetahui apakah ada perbedaan bobot badan dan bobot telur itik yang dipelihara secara intensif dan semi intensif. Hipotesis awal bahwa ada perbedaan antara bobot badan dan bobot telur Itik Magelang yang dipelihara secara intensif dan semi intensif.

\section{MATERI DAN METODE}

Sampel diperoleh dari beberapa peternak Itik Magelang yang ada di Dusun Sempu, Kecamatan Secang, Kabupaten Magelang. Jumlah sampel yang digunakan adalah 100 ekor itik dengan jumlah itik jantan 4 ekor dan itik betina 96 ekor. Analisa bobot telur menggunakan 100 butir Itik Magelang. Jenis pakan yang digunakan dalam pemeliharaan intensif yaitu bekatul, padi, jagung, dan konsentrat.

Pemeliharaan semi intensif pakan yang digunakan sama seperti pemelihaaan intensif dan terdapat pakan tambahan berupa cacing, keong, serangga kecil dan biji-bijian di area persawahan atau rawa-rawa. Analisa bobot badan ditimbang menggunakan timbangan dengan kapasitas $10 \mathrm{~kg}$ dan kepekaan 0,05 kg. Bobot telur ditimbang menggunakan timbangan dengan kapasitas 500 gram dengan kepekaan 0,01 gram. Data yang diperoleh kemudian di uji menggunakan uji paired sample $\mathrm{T}$ test.

Tabel 1. Data konsumsi pakan

\begin{tabular}{cccl}
\hline Periode & Umur (Minggu) & $\begin{array}{c}\text { Jumlah konsumsi pakan } \\
(\text { Gram/ekor/hari) }\end{array}$ & \multicolumn{1}{c}{ Sistem Pemeliharaan } \\
\hline Starter & $0-8$ & 120 & Intensif/Dikandangkan \\
Grower & $8-20$ & 150 & Intensif/Dikandangkan \\
Layer & $>20$ & 180 & $\begin{array}{l}\text { Semi intensif/ Dikandangkan dan } \\
\text { umbaran }\end{array}$ \\
\hline
\end{tabular}




\section{HASIL DAN PEMBAHASAN}

Itik Magelang menjadi ternak yang didominasi dan menjadi ternak yang dipelihara oleh peternak di Dusun Sempu. Survey yang dilakukan di beberapa peternak menunjukkan keberagaman ukuran fisiologis itik yang dipelihara. Dari bobot badan Itik Magelang yang dipelihara secara intensif dan semi intensif menunjukkan hasil sebagai berikut:

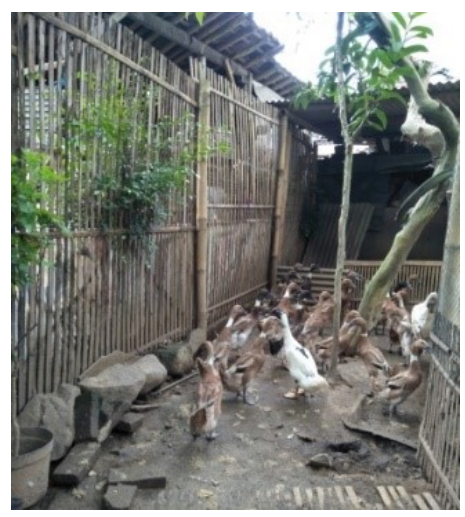

Gambar 1. Sistem Pemeliharaan Intesif

Sistem pemeliharaan intensif menunjukkan postur tubuh itik yang lebih kecil dibandingkan sistem pemeliharaan semi intensif, tingkat keaktifan itik cenderung kurang. Karena kontak langsung antara peternak dengan itik lebih tinggi. Pakan yang diberikan lebih teratur dan dan sesuai kebutuhan atau target yang yang akan dicapai oleh peternak tersebut terutama bobot badan yang ideal dan seragam. Bobot badan merupakan satu sifat kuantitatif yang dapat menggambarkan pola pertumbuhan Itik Magelang dan menjadi tolak ukur kualitas genetik dari Itik Magelang (Purwantini et al., 2019). Bobot badan rata-rata itik menunjukkan $1,41 \mathrm{~kg}$.

Dari data tersebut menunjukkan bahwa pemenuhan nutrisi masih kurang dari pakan yang diberikan terutama kandungan protein dan energi. Sedangkan menurut Rahayu et al (2019) menunjukkan bahwa bobot badan itik yaitu 1,94 $\mathrm{kg} /$ ekor. Hal tersebut kemungkinan disebabkan karena aktivitas yang terlalu berlebihan dan konsumsi energi pada pemeliharaan secara umbaran kurang (Wang et al., 2009 dan Liu et al., 2011). Dari pemaparan peternak menunjukkan bahwa pemeliharaan secara intensif dari segi postur tubuh lebih kecil namun hal tersebut dilakukan agar dapat mengurangi ancaman predator yang banyak berkembang terutama garangan dan ular. Keuntungan dari sistem pemeliharaan secara intensif akan membantu para peternak dalam mengatasi berbagai permasalahan mengenai manajemen pemeliharaan itik antara lain kualitas bibit dan pakan yang diberikan (Rahayu et al. 2019).

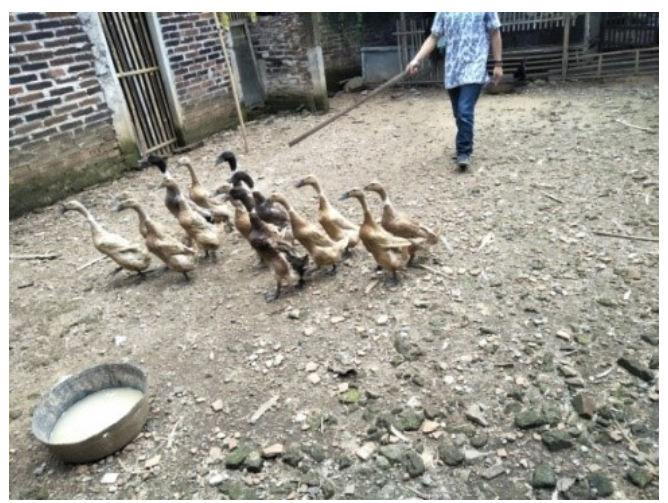

Gambar 2. Sistem pemeliharaan semi intensif

Peternak yang menggunakan sistem pemeliharaan semi intensif menunjukkan postur tubuh itik yang lebih besar dibandingkan dengan sistem pemeliharaan intensif. Bobot badan ratarata itik menunjukkan $1,68 \mathrm{~kg}$ setiap ekornya. Dari data yang diperoeh itik yang dipelihara meggunakan sistem pemeliharaan semi intensif yaitu pemeliharaan dilakukan didalam kandang dan di luar kandang. Itik akan di lepas atau di umbar diarea persawahan atau rawa-rawa untuk memperoleh pakan tambahan seperti cacing, keong, serangga kecil atau biji-bijian. Pemeliharaan intensif maupun semi intensif secara tradisional, itik akan mencari pakan dan nutrien sendiri baik digunakan untuk pertumbuhan maupun reproduksi. Namun, jika saat itu itik tidak mendapatkan nutrien tambahan maka kebutuhan nutrien itik akan rendah sehingga produksi telur tetap rendah. Ketika cuaca panas atau siang hari itik akan di giring

Tabel 2. Uji Paired Sample T Test bobot badan

\begin{tabular}{cccccccc}
\hline $\begin{array}{c}\text { Kode } \\
\text { itik }\end{array}$ & $\begin{array}{c}\text { Jumlah } \\
\text { (Ekor) }\end{array}$ & $\begin{array}{c}\text { Umur } \\
\text { (Bulan) }\end{array}$ & $\begin{array}{c}\text { Jenis } \\
\text { Pemeliharaan }\end{array}$ & $\begin{array}{c}\text { Rataan bobot } \\
\text { badan }(\mathrm{kg})\end{array}$ & $\begin{array}{c}\mathrm{T} \\
\text { hitung }\end{array}$ & $\begin{array}{c}\text { T tabel } \\
0,05\end{array}$ & Nilai Sig. \\
\hline P1 & 50 & Lebih dari 6 & Intensif & $1,418 \pm 0,023$ & 6,637 & 1,67655 & 0,000 \\
P2 & 50 & Lebih dari 6 & Semi Intensif & $1,683 \pm 0,032$ & & & \\
\hline
\end{tabular}


Tabel 3. Uji Paired Sample T Test bobot telur

\begin{tabular}{cccccccc}
\hline $\begin{array}{c}\text { Kode } \\
\text { Itik }\end{array}$ & $\begin{array}{c}\text { Jumlah } \\
\text { (Ekor) }\end{array}$ & $\begin{array}{c}\text { Umur } \\
\text { (Bulan) }\end{array}$ & $\begin{array}{c}\text { Jenis } \\
\text { pemeliharaan }\end{array}$ & $\begin{array}{c}\text { Bobot rata-rata } \\
\text { telur (Gram) }\end{array}$ & Nilai T & $\begin{array}{c}\text { T tabel } \\
0,05\end{array}$ & $\begin{array}{c}\text { Nilai } \\
\text { Sig. }\end{array}$ \\
\hline P1 & 50 & 6 & Intensif & $62,773 \pm 0,702$ & 32,242 & 1,67655 & 0,002 \\
P2 & 50 & 6 & Semi intensif & $65,974 \pm 0,696$ & 3,242 & \\
\hline
\end{tabular}

menuju kandang dan diberi pakan berupa campuran bekatul, padi, jagung, dan konsentrat dengan perbandingan 1:1:1:1. Penggiringan itik saat cuaca panas bertujuan untuk menghindari dehidrasi yang berlebih. Pemberian pakan tambahan menyebabkan itik yang banyak dipelihara oleh peternak memiliki tubuh yang relatif besar. Hal tersebut sesuai pendapat Yuwono (2012) yang menyatakan bahwa postur tubuh Itik Magelang relatif lebih besar dibandingkan jenis itik lainnya di Indonesia. Bobot badan itik yang beragam diakibatkan oleh konsumsi protein dan energi yang lebih tinggi akan menghasilkan laju pertumbuhan yang lebih cepat dan mencapai standar bobot itik 1,5 - $2 \mathrm{~kg}$ (Hanggara, 2013 dan Rahayu et al., 2019). Selain itu pertumbuhan juga dipengaruhi oleh genetik bawaan dari indukan sebelumnya (Meisji et al., 2012, Rahayu et al., 2015).

Pemeliharaan secara intensif dan semi intensif juga mempengaruhi bobot telur Itik Magelang. Telur yang dihasilkan secara pemelihaaran intensif menunjukkan bobot yang lebih kecil yaitu 62,77 gram/butir dibandingkan bobot telur yang dihasilkan itik dengan pemeliharaan semi intensif dengan bobot ratarata mempunyai bobot rata-rata $65,97 \mathrm{gram} / \mathrm{butir}$ (Tabel 3). Dari pengujian menggunakan paired sample $\mathrm{T}$ test terhadap bobot badan Itik Magelang dan bobot telur menunjukkan perbedaan yang signifikan dengan nilai signifikansi $\quad \mathrm{p}<0,05$. Pengaruh nutrisi berpengaruh besar terhadap bobot itik dan telur, bila perlakuannya dimulai sejak awal periode pertumbuhan.

Laju pertumbuhan, nutrisi, umur dan bobot tubuh adalah faktor-faktor yang mempunyai hubungan yang erat antara satu dengan yang lainnya terutama bobot itik dan telur. Pertambahan bobot itik juga akan berpengaruh terhadap lainnya seperti panjang badan, panjang leher, lingkar dada. Sistem pemeliharaan yang dilakukan secara semi intensif menunjukkan pertumbuhan yang bagus, terutama bobot badan yang tinggi dari keseluruhan itik. Selain itu, bobot telur yang dihasilkan juga tinggi. Pertumbuhan ternak tidak akan terganggu jika faktor lingkungan sekitar, pemeliharaan dan manajemen perkandangan terpenuhi dan dalam kondisi baik (Amaludin et al., 2013).

Pemeliharaan yang berbeda akan menghasilkan kualitas itik dan telur yang berbeda. Hal tersebut dapat dilihat terutama dari bobot badan, tingkat keagresifan itik, dan bobot telur yang dihasilkan. Itik yang dipelihara dengan sistem semi intensif memiliki bobot badan yang lebih tinggi dan lebih agresif atau aktif dibandingkan itik yang dipelihara secara intensif (Rahayu et al., 2020) (Luthfiana et al., 2020). Namun, resiko terpapar penyakit lebih tinggi, karena penyakit dapat ditularkan melalui kontak langsung, udara, atau hewan liar yang banyak membawa virus. Menurut Tamzil (2014), menyatakan bahwa suhu tubuh normal pada unggas berkisar antara $40,5-41,5^{\circ} \mathrm{C}$, sehingga untuk mempertahankan suhu tubuh ini, unggas dipelihara pada lingkungan dengan suhu berkisar antara $20-24^{\circ} \mathrm{C}$ dan kelembaban relatif sekitar $50-70 \%$.

\section{KESIMPULAN}

Dari pembahasan di atas dapat disimpulkan bahwa sistem pemeliharaan semi intensif berpengaruh nyata terhadap pertambahan bobot badan Itik Magelang dan bobot telur dibandingkan dengan sistem intensif. Kelebihan dari pemeliharaan intensif yaitu memudahkan dalam pemberian pakan, sedangkan kelemahannya yaitu bobot badan sulit mencapai target yang diharapkan. Kelebihan dari pemeliharaan semi intensif yaitu dapat meminimalisir biaya pakan karena mendapat pakan tambahan dari umbaran yang dilakukan, sedangkan kelemahannya yaitu sulitnya untuk melakukan pengontrolan pakan, kesehatan dan bobot badan.

\section{UCAPAN TERIMA KASIH}

Peneliti mengucapkan terima kasih kepada Direktorat Riset dan Pengabdian Masyarakat Direktorat Jenderal Riset dan Pengembangan Kementerian Riset, Teknologi, dan Pendidikan Tinggi tahun 2020 yang telah mendanai Penelitian Dosen Pemula (PDP) ini 
berdasarkan SK No. B/87/E3/RA.00/2020 tanggal 28 Januari 2020.

\section{DAFTAR PUSTAKA}

Amaludin, F., I. Suswono, Rusdiyanto. 2013. Bobot dan Presentase Bagian-Bagian Karkas Itik Mojosari Afkir Berdasarkan Sistem Dan Lokasi Pemeliharaan. Jurnal Ilmiah Peternakan 1(3):924-932.

Dinas Peternakan dan Perikanan Kabupaten Magelang. 2015. Populasi dan Jenis Unggas Itik Magelang. Magelang.

Hanggara, D. S. 2013. Pengaruh Tingkat Pembatasan Protein dalam Ransum terhadap Edible dan In Edible pada Itik Jantan Lokal. Studens e-journal. Fakultas Peternakan. Universitas Padjadjaran. Bandung .

Ismoyowati dan D. Purwantini. 2013. Produksi dan Kualitas Telur Itik Lokal di Daerah Sentra Peternakan Itik. Jurnal Pembangunan Pedesaan 13(1):11-16.

Kementrian Pertanian. 2013. Keputusan Menteri Pertanian Nomor 701/Kpts/PD.410/2/2013 tentang Penetapan Rumpun Itik Magelang. Kementrian Pertanian. Jakarta.

Keputusan Menteri Pertanian. 2013. Penetapan Rumpun Itik Magelang. Nomor 701/Kpts/PD.410/2/2013. Menteri Pertanian. Jakarta.

Liu, B.Y., Z.Y. Wang, H. M.Yang, J. M. Wang, D. Xu, R. Zhang, and Q. Wang. 2011. Influence of rearing system on growth performance, carcass traits, and meat quality of Yangzhou geese. Poultry Science 90: 653-659.

Luthfiana, N.A., B. Santoso, dan A. Rahayu. 2020. Korelasi Genetik antara Bobot Telur dengan Indeks Telur Itik Magelang di Dusun Sempu, Desa Ngadirojo, Kecamatan Secang, Kabupaten Magelang. Prosiding Seminar Nasional Fakultas Pertanian UNS "Strategi Ketahanan Pangan Masa New Normal COVID-19" 4 (1): 382-387.
Meisji, L. S., R.R. Noor, P.S. Hardjosworo dan C. Nisa. 2012. Kajian karakteristik biologis itik pegagan Sumatera Selatan. J. Lahan Suboptimal 1(2): 170-176.

Purwantini, D., R.S.S. Santosa, S.A. Santosa, Ismoyowati, and A. Rahayu. 2019. Heterosis Value Estimation of Magelang and Tegal Cross Ducks Morphometrics Characteristics. IOP Conference Series: Earth and Environmental Science 372 (1) : 1- 5 .

Rahayu, A., D. Purwantini, D. Maharani, and T. Hartatik. 2015. Single Nucleotide polymorphism Identification and Genotyping Anaysis of Melanocortin 1 Receptor Gene in Various Plumage Colors Magelang Duck. International Journal of Poultry Science 14: 207-212.

Rahayu, A., B. Santoso., N. A. Luthfiana. 2019. Identification of Magelang Ducks to Know Morphological Diversity in Ngadirojo Village, Secang District, Magelang Regency. Journal of Livestock Science and Production 3(2): 179-185.

Rahayu, A., dan T. P. Rahayu. 2020. Manajemen Pemeliharaan Itik Magelang secra Intensif dan Ektensif di Kecamatan Secang, Kabupaten Magelang. Bulletin of Applied Animal Research. 2 (2): 3843.

Tamzil, H. 2014. Stres Panas pada Unggas: Metabolisme, Akibat dan Upaya Penanggulangannya. Wartazoa 24(2): 5766.

Wang, K.H., S.R. Shi, T. C. Dou, and H. J. Sun. 2009. Effect of a free-raising system on growth performance, carcass yield, and meat quality of slow-growing chicken. Poultry Science 88: 2219-2223.

Wulandari, D., Sunarno, T. R. Saraswati. 2015. Perbedaan Somatometri Itik Tegal, Itik Magelang Dan Itik Pengging. Bioma 17(2): 94-101.

Yuwono, M. D. 2012. Budidaya Ternak Itik Petelur. Perpustakaan Nasional RI. Ungaran. 